\title{
Peran Unit Kegiatan Mahasiswa (UKM) Pramuka Dalam \\ Membangun Harmoni Ditengah Kemajemukan (Studi \\ Kasus Pembentukan Karakter Kepemimpinan \\ Pada Unit Kegiatan Pramuka IAIN Metro)
}

\author{
Muhammad Ali \\ Institut Agama Islam Negeri (IAIN) Metro \\ E-mail: muhammadghoni@gmail.com
}

\begin{abstract}
Students of the State Islamic Institute (IAIN) in general and members of SME Scout IAIN Metro, especially coming from different ethnic backgrounds, economic and culturally different, then you can bet they have behaviors and traditions that are different, therefore the students should be able to use reasonable mind in the act or behave as a result of an assessment of things, objects, events that occur or are facing in order to create harmony amid diversity of cultures and customs that are owned, life is full of peace, comfort, and tolerance is the goal of everyone. The purpose of this paper is to investigate the role of SMEs in shaping the character Scout leadership. 2). To determine the inhibiting factors in shaping the character of leadership. 3).
\end{abstract}

Keywords: Student Activity Unit Scouts, Leadership Character, Pluralism.

\begin{abstract}
Abstrak
Mahasiswa Institut Agama Islam Negeri (IAIN) pada umumnya dan anggota UKM Pramuka IAIN Metro khususnya berasal dari latar belakang suku, ekonomi dan budaya yang berbeda-beda, maka dapat dipastikan mereka memiliki perilaku dan tradisi yang berbeda pula, oleh karena itu mahasiswa harus mampu menggunakan akal pikirannya dalam bertindak atau bersikap sebagai hasil penilaian terhadap sesuatu, objek, peristiwa yang terjadi atau yang dihadapi guna terciptanya harmonisasi ditengah tengah aneka ragam budaya dan adat istiadat yang dimiliki, Kehidupan yang penuh kedamaian,
\end{abstract}


kenyamanan, dan toleransi merupakan tujuan semua orang. Tujuan penulisan ini adalah untuk mengetahui peran UKM Pramuka dalam pembentukan karakter kepemimpinan. 2). Untuk mengetahui faktor penghambat dalam pembentukan karakter kepemimpinan. 3). Untuk mengetahuipa saja yang menjadi faktor pendukung dalam pembentukan karakter kepemimpinan.

Kata Kunci: Unit Kegiatan Mahasiwa Pramuka, Karakter Kepemimpinan, Kemajemukan.

\section{A. Pendahuluan}

\section{Latar Belakang Maslah}

Mahasiswa Institut Agama Islam Negeri (IAIN) pada umumnya dan anggota UKM Pramuka IAIN Metro khususnya berasal dari latar belakang suku Ekonomi dan budaya berbeda-beda, maka dapat dipastikan mereka memiliki perilaku dan tradisi yang berbeda dalam hal ini Sartini mengemukakan Kearifan lokal atau sering disebut local wisdom dapat dipahami sebagai usaha manusia dengan menggunakan akal budinya (kognisi) untuk bertindak dan bersikap terhadap sesuatu, objek, atau peristiwa yang terjadi dalam ruang tertentu. ${ }^{1}$

Sementara Ridwan, berpendapat secara etimologi, di mana wisdom dipahami sebagai kemampuan seseorang dalam menggunakan akal pikirannya dalam bertindak atau bersikap sebagai hasil penilaian terhadap sesuatu, objek, atau peristiwa yang terjadi. ${ }^{2}$ Sementara itu Parsudi Suparlan mengemukakan akar kata dari multikulturalisme adalah kebudayaan, yaitu kebudayaan yang dilihat dari fungsinya sebagai pedoman bagi kehidupan manusia. ${ }^{3}$

\footnotetext{
${ }^{1}$ Sartini.Menggali Kearifan Lokal Nusantara Sebuah Kajian Filsafati . Jurnal Filsafat, 2004, Jilid 37, Nomor 2 , 111.

${ }^{2}$ Ridwan, N. A. Landasan Keilmuan Kearifan Lokal. Ibda P3M STAIN Purwokerto, 2007, Vol 5 No.1 , 27-38.

${ }^{3}$ Suparlan, Parsudi, Menuju Masyarakat Indonesia Yang Multikultural, Makalah, Disajikan pada Simposium Internasional Jurnal Antropologi Indonesia ke-3, Universitas Udayana, Denpasar, Bali, 16-19 Juli 2002.
} 
Dengan demikian maka karakter dan mindset berpikir beraneka ragam yang dimiliki akan mempengaruhi pola kepemimpinan yang ada, fenomena yang terjadi saat ini mahasiswa Institut Agama Islam Negeri (IAIN) Metro, mengalami krisis sumber daya manusia yang memiliki karakter kepemimpinan salah satu contoh sudah dua tahun Dewan Mahasiswa (DEMA) dan Senat Mahasiswa (SEMA) mengalami kekosongan kepengurusan, dua tahun juga Presiden Mahasiswa tidak menyampaikan Laporan Pertanggung Jawaban (LPJ) bahkan pelaksanaan kongrespun tidak selesai. ${ }^{4}$ Ini pertanda ketidakmampuan mahasiswa untuk menyatukan keaneka ragaman pola pikir yang dimiliki, seharusnya hal ini tidak boleh terjadi dikalangan mahasiswa khususnya di IAIN Metro. Karena itu semua adalah sebuah wadah yang mampu menampung dan penyalurkan inspirasi mahasiswa, disisi lain akibat dari tidak berjalannya roda kepemimpinan organisasi DEMA, SEMA yang ada maka akan terputuslah rantai kaderisasi calaon-calon pemimpin yang handal dan siap pakai dimasa yang akan datang. Dengan demikian maka mahasiswa sebagai calon generasi pemimpin yang akan datang seharusnya memiliki jiwa kepemimpinan yang baik, mengedepankan kemasalahatan orang banyak di atas kepentingan organisasi, suku dan budaya yang dimiliki atau mereka anut masing-masing.

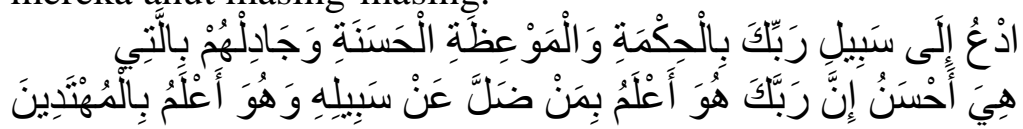

( 1 Yo)

Serulah (manusia) kepada jalan Tuhan-mu dengan hikmah dan pelajaran yang baik dan bantahlah mereka dengan cara yang baik. Sesungguhnya Tuhanmu Dialah yang lebih mengetahui tentang siapa yang tersesat dari jalan-Nya dan Dialah yang lebih mengetahui orang-orang yang mendapat petunjuk. ${ }^{5}$

${ }^{4}$ BulitinKronikaEdisi 24, 2016, hlm. 5

${ }^{5}$ (QS. Annahl:125) 


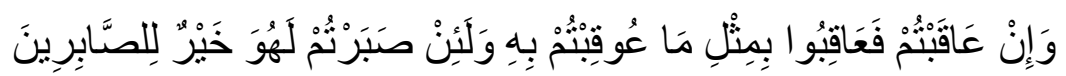

( I Y T)

Dan jika kamu memberi balasan, maka balaslah dengan balasan yang sama dengan siksaan yang ditimpakan kepadamu, Akan tetapi jika kamu bersabar, sesungguhnya itulah yang lebih baik bagi orang-orang yang bersabar. ${ }^{6}$

(An-Nahl 16:126).

Dari ayat di atas dapat dipahami bahwa Allah mengajarkan kepada kita untuk hidup toleransi dan bersabar atas semua yang kita lalui serta berbuat yang terbaik. Orang yang memiliki kematangan emosional dan berjiwa besar akan mampu mengantarkan seseorang menjadi yang terbaik.

Dalam sebuah kepemimpinan itu dipandang sangat penting untuk memahami sebuah perbedaan sudut pandang baik pola pikir, organisasi, suku, budaya maupun agama, karena seorang pemimpin harus mampu menengahi, mengayomi, menyatukan semua golongan untuk mencapai sebuah kepentingan dan tujuan yang telah disepakati bersama. Toleransi terhadap perbedaan baik sudut pandang pikiran, suku, budaya bahkan agama harus dikedepankan agar terciptanya sebuah kesejukan dalam sebuah tatanan organisasi maupun masyarakat.

Kehidupan yang penuh kedamaian, kenyamanan, dan toleransi merupakan tujuan semua orang. Karena tidak ada satu agama,kehidupan sosial yang menyukai konflik kekerasan, semua orang memiliki harapan hidup dalam kedamaian dan toleransiantar mereka sekalipun berbeda dalam banyak hal, hidup penuh toleran dan saling berdampingan tanpa harus memandangperbedaan baik suku budaya dan sudut pandang, merupakan impian idealsetiap manusia.

Kemerosotan moral mahasiswa akan mempengaruhi corak dan kualitas bangsa di masa depan. Kondisi

${ }^{6}(\mathrm{QS} . \mathrm{An}-\mathrm{Nahl}: 126)$ 
tersebut diperparah dengan menurunnya wawasan kebangsaan generasi mahasiswa yang ditunjukkan dengan mengedepankan ego masing-masing, berbuat dan bertidak sesukanya tidak lagi mengedepankan musyawarah dan mupakat namun lebih kepada mengikuti keinginan masingmasing.

Oleh karena itu perubahan-perubahan yang terjadi dalam lingkungan sosial dikalangan mahasiswa saat ini memerlukan sosok pemimpinya yang dapat menyatukan kebinikaan baik suku, organisasi dan budaya, yang nantinya mampu membawa lembaga Perguruan Tinggi khususnya Institut Agama Islam Negeri (IAIN) Metro kearah yang lebih baik.

Salah satu solusi untuk membentuk karakter kepemimpinan yang mampu menyatukan keanekaragaman latar belakang mahasiswa baik suku, organisasi serta budaya. Gerakan Pramuka sebagai media pendidikan karakter sesuai dengan amanah Undang-Undang Gerakan Pramuka No. 12 tahun 2010 menjelaskan Gerakan Pramuka merupakan organisasi yang menyelenggarakan pendidikan kepramukaan, pramuka merupakan wadah pendidikan generasi muda usia 7-25 tahun, yang mempersiapkan anggotanya agar memiliki karakter yang sesuai dengan dasadarma dan tri satya. ${ }^{7}$

Berdasarkan uraian di atas, maka sangat penting untuk mengadakan penelitian tentang" Peran UKM Pramuka dalam Membangun Harmoni ditengah Kemajemukan (Studi Pembentukan Karakter Kepemimpinan pada Unit KegiatanPramuka IAIN Metro)

\section{Rumusan Masalah}

Berdasarkan latar belakang masalah tersebut maka persoalan yang menjadi fokus masalah dalam penelitian ini adalah: 1). Bagaimana Peran UKM Pramuka dalam pembentukan karakter kepemimpinan? 2). Apa saja yang

${ }^{7}$ Undang-UndangRepublik Indonesia No 12 Tahun 2010 TentangGerakanPramuka, hlm.9 
menjadi faktor penghambat/kendala dalam pembentukan karakter kepemimpinan? 3). Apa saja yang menjadi faktor pendukung dalam pembentukan karakter kepemimpinan?

\section{Metode Penelitian}

Jenis Penelitian ini adalah penelitian lapangan (field research), sebuah penelitian dengan prosedur penelitian yang menggali data dari lapangan untuk kemudian dicermati, dianalisis dan disimpulkan. Adapun sifat penelitian ini adalah kualitatif.Penelitian kualitatif bersifat alamiah dan menghendaki keutuhan sesuai dengan masalah yang telah dirumuskan penulis sebelumnya, yakni mendeskripsikan Peran UKM Pramuka dalam pembentukan karakter kepemimpinan.

Dalam penelitian ini data yang digunakan adalah pertama Primer yang diperoleh secara langsung dari sumber asli, yang penulis dapatkan langsung dari Pembina Pramuka, Ketua Dewan Racana, Anggota Dewan dan Anggota Racana IAIN Metro, melalui proses wawancara dan dokumentasi kepada Pembina Pramuka, Ketua Dewan Racana, Anggota Dewan serta Anggota Racana. Obyek dalam penelitian ini adalah gambaran tentang Peran UKM Pramuka dalam pembentukan karakter kepemimpinan.Kedua data sekunder, yang diperoleh dari sumber pendukung untuk melengkapi dan memperjelas sumber primer, yang berupa perpustakaan yang berhubungan erat dengan obyek penelitian. Data ini diperoleh dari literatur-literatur, ensiklopedi dan kebijakankebijakan serta data resmi dari lembaga yang dijadikan lokasi peneliti. Teknik analisa data mengunakan pendekatan kualitatif, dengan menganalisa hasil penelitian yang mengasilkan data deskriptif analisis melalui reduksi data, display data, verifikasi atau penarikan kesimpulan. 


\section{B. Kajian Teoritik}

\section{Karakter}

\section{a. Pengertian Karakter}

Doni Koesoema. A mengatakan bahwa karakteradalahbawaan, hati, jiwa, kepribadian, maupun budi pekerti, perangai, perilaku, personalitas, sifat, tabiat, temperamen, watak. ${ }^{8}$ Karakter secara etimologis berasal dari bahasa Yunani "karasso", berarti 'cetak biru', 'format dasar', 'sidik' seperti dalam sidik jari. ${ }^{9}$ Karakter juga diartikan sebagai watak, yaitu sifat batin manusia yang mempengaruhi segenap pikiran dan tingkah laku atau kepribadian yang didalamnya terdapat unsur pengetahuan, perasaan dan dorongan naluri. Beberapa tokoh juga mendefinisikan karakter, adalah kualitas atau kekuatan mental,moral, akhlak serta budi pekerti individu yang merupakan kepribadian khusus yang menjadi pendorong dan penggerak, yang membedakan individu dengan individu lain. ${ }^{10}$

Mengacu pada berbagai pengertian karakter tersebut yang ada, maka karakter dapat dimaknai sebagai nilai dasar yang membangun pribadi seseorang, baik karena pengaruh hereditas maupun pengaruh lingkungan, yang membedakannya dengan orang lain serta diwujudkan dalam sikap dan perilaku dalam keseharian, serta sifat dasar seseorang.

${ }^{8}$ Tim Penyusun Tesaurus, Tesaurus Alfabetis Bahasa Indonesia Pusat Bahasa (Bandung: Mizan Pustaka, 2009), hlm. 273.

${ }^{9}$ Doni Koesoema A, Pendidikan Karakter Strategi Mendidik Anak di Zaman Global (Jakarta: Grasindo, 2010), hlm. 90.

10 M. FurqonHidayatullah, PendidikanKarakter: MembangunPeradabanBangsa., hlm. 13. 


\section{b. Nilai-nilai Karakter}

Berikut ini merupakan nilai-nilai karakter yang dapat dijadikan dasardan diinternalisasikan kepada peserta didik.

1. Nilai karakter terkait dengan Tuhan. Nilai ini bersifat religius, artinya pikiran, perkataan, perbuatan selalu berdasarkan pada nilai-nilai ketuhanan.

2. Nilai karakter terkait hubungannya dengan diri sendiri, meliputi: jujur, bertanggung jawab, disiplin, kerja keras, percaya diri, berjiwa wirausaha, berpikir (logis, kritis, inovatif, kreatif).

3. Nilai karakter dalam hubungannya dengan sesama, meliputi: sadar akan hak dan kewajiban terhadap diri sendiri maupun orang lain, patuh pada aturanaturan sosial, menghargai karya dan prestasi orang lain, santun, serta demokratis.

4. Nilai karakter twerkait hubungan dengan lingkungan, meliputi: peduli terhadap kehidupansosial

5. Nilai kebangsaan, meliputi: nasionalis, menghargai keberagaman.

Dari publikasi pusat kurikulum dinyatakan bahwa pendidikan karakter berfungsi: mengembangkan potensi dasar seseorang agar memiliki berhati, pikiran serta berperilaku yang baik; memperkuat dan membangun perilaku sebuah bangsa yang multikultur; meningkatkan peradaban yang kompetitif padapergaulan dunia. Renata sebagaimana diungkapkan oleh Cahyono dkk mengatakan pendidikan karakter adalah sebuah sistem yang menanamkan nilai-nilai karakter pada peserta didik, 
yangmengandung komponen pengetahuan, kesadaran individu, tekad, serta adanya kemauan dan tindakan untuk melaksanakan nlai-nilai, baik terhadap Tuhan Yang Maha Esa, diri sendiri, sesama manusia, lingkungan, maupun bangsa, sehingga akan terwujud insan kamil. $^{11}$

Dari phenomena di atas dapatdiidentifikasi nilai pembentuk karakter merupakan hasil kajian empirik pusat kurikulum.Yaitu Nilai-nilai yang bersumber dari agama, pancasila, budaya, dan tujuan pendidikan nasional tersebut adalah religius, jujur, toleransi, disiplin, kerja keras, kreatif, mandiri, demokratis, , semangat kebangsaan, cinta pada tanah air, menghargai prestasi, bersahabat, cinta damai, gemar membaca, peduli lingkungan sosial, serta tanggung jawab. ${ }^{12}$

Dari nilai-nilai karakter di atas dapat diketahui bahwa seseorang yang mempunyai karakter yang baik terkait dengan Tuhan, seluruh kehidupannya akan baik. Dengan mengetahui nilai-nilai karakter di atas dapat diketahui banyak nilai karakter yang harus disampaikan dan diajarkan kepada anggota pramuka/ peserta didik melalui kegiatan ataupun sistem manajemen lembaga tersebut mulai dari karakter yang terkait dengan Tuhan, karakter terkait dengan diri sendiri, karakter terkait dengan sesama manusia, karakter terkait dengan lingkungan dan karakter terkait dengan kebangsaan dalam rangka pembentukan karater peserta didik Gerakan Pramuka Institut Agama Islam Negeri (IAIN)

${ }^{11}$ Heri Cahyono, Suhono Suhono, dan Aisah Khumairo, "Pendidikan Karakter Bagi Pelaku Pedofilia (Sebuah Strategi Dalam Mengatasi Amoral)," JMKSP (Jurnal Manajemen, Kepemimpinan, dan Supervisi Pendidikan) 3, no. 1 (t.t.): 8.

${ }^{12}$ MuchlasSamani, Hariyanto,Konsepdan Model Pendidikan., hlm. 52 
Metro.Semua karakter diatas harus dimiliki oleh anggota pramuka sehingga kelak mampu menciptakan harmonisasi ditengah kemejemukan mahasiswa IAIN Metro dan masyarakat.

\section{c. Prinsip Pendidikan Karakter}

Menurut pendapat Tom Lickona,Eric Schaps, Catherine Lewis, yang dikutif oleh Anton Suwitomenyebutkan adanya sebelas prinsip pendidikan karakter efektif antara lain: ${ }^{13}$

a. Mempromosikan nilai-nilai inti dan nilai-nilai Ethica kinerja mendukung sebagai landasan Karakter baik.

b. Mendefinisikan "karakter" secara komprehensif toinclude pemikiran, perasaan, dan perilaku.

c. Menggunakan pendekatan yang komprehensif, disengaja, dan proaktif untuk pengembangan karakter.

d. Menciptakan komunitas sekolah yang peduli.

e. Memberikan siswa dengan peluang untuk tindakan moral.

f.Termasuk kurikulum akademik yang bermakna dan menantang yang menghormati semua peserta didik, mengembangkan karakter mereka, dan membantu mereka untuk berhasil.

g. Berusaha untuk mendorong siswa motivasi diri.

h. Melibatkan sekolah dalampembentukan karakter upaya untuk mematuhi nilai-nilai inti ke Ketuhanan

i. Fosters kepemimpinan moral bersama dan dukungan arange panjang dari inisiatif pendidikan karakter (lanjutan)

j. Melibatkan keluarga dan anggota masyarakat sebagai mitra dalam upaya pembangunan karakter.

13 Anton Suwito, IntegrasiNilaiPendidikanKarakterKedalam Mata PelajaranPendidikanKewarganegaraan di SekolahMelalui RPP, (JurnalIlmiah CIVIS Vol. 2 No. 2, 2012) 
k. Menilai karakter sekolah, fungsi staf sekolah sebagai pendidik karakter, dan sejauh mana siswa memanifestasikan karakter yang baik.

Dari sebelas prinsip pendidikan karakter di atas yang harus diwujudkan dalam kehidupan anggota pramuka IAIN Metro melalui kegiatan-kegiatan yang dilaksanakan baik bina diri, bina satuan dan bina masyarakat.

\section{d. Faktor-faktor yang Akan Mempengaruhi Karakter}

Dalam pembentukan karakter ditentukan oleh dua faktor yaitu:Nature (Faktor Alami atau Fitrah). Agama mengajarkan bahwa setiap manusia kecenderungan mencintai kebaikan. Namun fitrah ini bersifat potensial (termanifestasikan). Setiap anak yang terlahir belum bisa mengendalikan dirinya sendiri. Faktor yang kedua Nurture (Faktor Lingkungan). Faktor lingkungan yang mempengaruhi karakter terbagi menjadi dua Pendidikan dan Sosialisasi (Sosialisasi dalam Keluarga, Sosialisasi dalam Sekolah, dan Sosialisasi dalam Masyarakat).

\section{e. Strategi Pembentukan Karakter}

Strategi dalam pendidikan karakter dapat dilakukan melalui sikap-sikap sebagai berikut: ${ }^{14}$

1.Keteladanan

Faktor penting dalam mendidik adalah terletak pada "keteladanannya". Keteladanan yang bersifat multidimensi, yakni keteladanan dalam berbagai aspek kehidupan. Ada beberapa cara dalam penyampaian keteladanan, yaitu melalui guru dan orang tua secara langsung menyampaikan atau mencontohkan kepada anak didik berupa sikap, perbuatan, perkataan yang menjadi nilai

${ }^{14}$ DwiYuni Lestari,PembinaanKarakterSiswa di SMP NasionalPati, (JurnalIlmiah PPKN IKIP Veteran Semarang, tt), hlm. 54-55

Fikri, Vol. 3, No. 1, Juni 2018 
sebagai motivasi untuk belajar anak. ${ }^{15}$ Keteladanan bukan hanya sekedar memberikan contoh dalam melakukan sesuatu, tetapi juga menyangkut berbagai hal yang dapat diteledani. Setidaktidaknya ada 3 unsur yaitu agar seseorang dapat diteladani atau menjadi teladan, yaitu: Kesiapan untuk dinilai dan dievaluasi, Memiliki kompetensi minimal, Memiliki integritas moral.

2. Penanaman Kedisiplinan

Disiplin pada hakikatnya adalah suatu ketaatan yang sungguh-sungguh yang didukung oleh kesadaran untuk menunaikan tugas kewajiban serta berperilaku sebagaimana mestinya menurut aturan-aturan atau tata kelakuan yang seharusnya berlaku didalam suatu lingkungan tertentu.

3. Pembiasaan

Ahmad ddk menjeaskan Proses pembentukan karakter dimulai dari pengenala perilaku baik dan buruk dan pembiasaan perilaku baik dalam kehidupan sehari-hari. Pada usia pra sekolah, pendidikan karakter efektif dilakukan oleh keluarga. ${ }^{16}$ Kegiatan pembiasaan ini secara spontan dapat dilakukan misalnya saling menyapa, baik antar teman, antar gurumaupun antar guru dengan murid. Pembiasaan diarahkan pada upaya pembudayaan pada aktifitas tertentu sehingga menjadi aktifitas yang terpola atau tersistem.

4. Menciptakan Suasana yang Kondusif

15 Suhono Suhono dan Ferdian Utama, "KETelADANAN ORANG TUA DAN GURU DALAM PERTUMBUHAN DAN PERKEMBANGAN ANAK USIA DINI," Elementary: Jurnal Ilmiah Pendidikan Dasar 3, no. 2 (2017): 107-119.

${ }^{16}$ Syarwani Ahmad dkk., "Desain Pembelajaran SMA Plus Negeri 2 Banyuasin III Berbasis Karakter Di Era Masyarakat Ekonomi ASEAN," Iqra': Jurnal Kajian Ilmu Pendidikan 2, no. 2 (2017): 7. 
Menciptakan suasana yang kondusif di sekolah merupakan upaya membangun kultur atau budaya yang memungkinkan untuk membangun karakter, terutama berkaitan dengan budaya kerja dan belajar di sekolah. Sekolah yang membudayakan warganya gemar membaca, tentu akan menumbuhkan suasana kondusif bagi siswa-siswanya untuk gemar membaca. Demikian sekolah yang membiasakan warganya untuk disiplin, aman, dan bersih, tentu juga akan memberikan suasana untuk terciptanya karakter yang demikian.

5. Integrasi dan Internalisasi

Pendidikan karakter sebaiknya dilaksanakan secara terintegrasi dan terinternalisasi ke dalam seluruh kehidupan sekolah. Terintegrasi, karena pendidikan karakter memang tidak dapat dipisahkan dengan aspek lain dan merupakan landasan dari seluruh aspek termasuk seluruh mata pelajaran. Terinternalisasi, karena pendidikan karakter harus mewarnai seluruh aspek kehidupan.

\section{Kepemimpinan}

\section{a. Pengertian Kepemimpinan}

Sacara etomologi (asal kata) menurut kamus besar Bahasa Indonesia, berasal dari kata "pimpin" dengan mendapat awalan "me" yang berarti menuntun, menunjukkan jalan dan membimbing. Perkataan lain yang disamakan artinya yaitu mengetuai, mengepalai, memandu dan melatih dan dalam bentuk kegiatan, maka si pelaku disebut "pemimpin". Maka dengan kata lain, pemimpin adalah orang yang memimpin, mengetuai atau mengepalai. Kemudian berkembang pula istilah "kepemimpinan" (dengan tambahan awalan ke) yang menunjukkan pada aspek kepemimpinan"

Secara terminology kepemimpinan adalah aktivitas untuk mempengaruhi perilaku orang lain agar supaya 
mereka mau diarahkan untuk mencapai tujuan tertentu. ${ }^{17}$ Menurut Robbins, kepemimpian adalah kemampuan untuk mempengaruhi suatu kelompok untuk mencapai tujuan. ${ }^{18}$ Sedangkan menurut Ngalim Purwanto kepemimpinan adalah sekumpulan dari serangkaian kemampuan dan sifat-sifat kepribadian, termasuk didalamnya kewibawaan, untuk dijadikan sebagai sarana dalam rangka meyakinkan yang dipimpinnya agar mereka mau dan dapat melaksanakan tugas-tugas yang dibebankan kepadanya dengan rela, penuh semangat, ada kegembiraan batin, serta merasa tidak terpaksa. ${ }^{19}$ Fungsi kepemimpinan harus dilandasi dengan mengedepankan kepentingan secara umum untuk mengayomi dan melayani, bukan sebaliknya malah pemimpin yang ingin diayomi dan dilayani. ${ }^{20}$ Jadi dapat diambil suatu kesimpulan bahwa pengertian kepemimpinan secara umum adalah proses mempengaruhisekelompok orang sehingga mau bekerja dengan sungguh-sungguh untuk meraih tujuan tertentu.

\section{b. Sifat-sifat yang Harus dimiliki Pemimpin}

Sepuluh sifat yang unggul yaitu. ${ }^{21}$

1. Kekuatan

2. Stabilitas emosi

3. Pengatahuan tentang relasi insani

4. Kejujuran

5. Objektif

${ }^{17}$ Miftah Thoha, Kepemimpinan dalam Manajemen, (Jakarta: Rajawali Pers, 1983), hlm. 123.

${ }^{18}$ Stephen P. Robbins, Prinsip-prinsip Perilaku Organisasi, (Jakarta: Erlangga, 2002), hlm. 163.

${ }^{19}$ M. Ngalim Purwanto, Administrasi dan Supervisi Pendidikan, (Bandung: Remaja Rosdakarya, 1991), hlm. 26.

${ }^{20}$ Eko Nani Fitriono dan Suhono Suhono, "Wacana Negara Islam: Kajian Kritis Kontruksi Pemikiran Khilafah Ala Hizbut Tahrir," Ri'ayah: Journal of Social and Religious 2, no. 02 (2017): 43-55.

${ }^{21}$ Kartini Kartono, Pemimpin dan Kepemimpinan, Jakarta: PT. RajaGrafindo Persada, 1983, hlm, 43-50. 
6. Dorongan pribadi

7. Ketrampilan berkomunikasi

8. Kemampuan mengajar

9. Ketrampilan sosial

10. Kecakapan manajerial.

Jadi, dengan demikian diharapkan seorang pemimpin itu harus berbudi luhur dan memiliki sifat-sifat utama, sehingga dia bisa membawa anak buahnya pada keselamatan dan kesejahteraan.

\section{Kegiatan Kepramukaan}

\section{a. Pengertian Pramuka}

Gerakan Pramuka adalah organisasi yang dibentuk untuk menyelenggarakan pendidikan kepramukaan.Pramuka adalah warga negara Indonesia yang aktif dalam pendidikan kepramukaan serta mengamalkan Satya Pramuka dan Darma Pramuka.Kepramukaan adalah segala aspek yang berkaitan dengan pramuka. ${ }^{22}$

Peraturan Menteri Pendidikan dan Kebudayaan Nomor : 63 Tahun 2014 tentang Pendidikan Kepramukaan sebagai kegiatan ekstrakurikuler wajib pada Pendidikan Dasar dan Pendidikan Menengah. Kegiatan ekstrakurikuler wajib diikuti oleh seluruh peserta didik.Pendidikan kepramukaan dilaksanakan untuk menginternalisasikan nilai ketuhanan, kebudayaan, kepemimpinan, kebersamaan, sosial, cinta alam, dan kemandirian pada peserta didik.

Pramuka juga dapat membentuk karakter pribadi seseorang.Seperti misalnya dapat membentuk sifat kedislipinan dalam setiap diri anggotanya.Tujuan dari pramuka tersebut sendiri adalah mendidik dan membina remaja untuk mengembangkan mental, moral, spiritual,

${ }^{22}$ Undang-Undang Nomor 12 tahun 2010 tentang Gerakan Pramuka Pasal 1 ayat 1-3. 
intelektual para remaja untuk menjadi pemuda yang baik dan berguna.

\section{b. Sifat Kepramukaan}

Resolusi Konfrensi Kepramukaan Sedunia tahun 1924, di Kopenheg, Denmark menyatakan bahwa kepramukaan memiliki 3 sifat, yakni : 1) Nasional, artinya kepramukaan itu diselenggarakan di masing- masing negara disesuaikan dengan kebutuhan masing-masing negara tersebut. 2) Internasional, artinya kepramukaan harus dapat mengembangkan rasa persaudaraan dan persahabatan antar sesama anggota ke panduan (pramuka) dan sebagai sesama manusia. 3) Universal, artinya kepramukaan itu dapat berlaku untuk siapa saja serta dapat diselenggarakan dimana saja. ${ }^{23}$

Dari pendapat di atas dapat di pahami bahwa Oganisasi kepramukaan adalah bukan hanya bersifat nasional bahkan dunia yang beranggotakan bermacam agama, suku, budaya dan sosial, dengan kemejemukan yang ada anggota pramuka telah mampu membuktikan kepada dunia bahwa Peraja Muda Karana (PRAMUKA) mamapu membangun kebersamaan (harmoni) dan toleransi yang baik.

\section{c. Fungsi Kepramukaan}

Seperti halnya dengan sifat-sifat kepramukaan, fungsi kepramukaan juga terdiri dari tiga fungsi yaitu : 1) Merupakan kegiatan yang menarik yang mengandung pendidikan, bagi anak-anak, remaja dan pemuda. 2) Merupakan suatu pengabdian (job) bagi para anggota dewasa yang merupakan tugas yang memerlukan keikhlaan, kerelaan dan pengabdian. 3) Merupakan alat (means) bagi masyarakat, negara atau

${ }^{23}$ Andri Bob Sunardi, Boyman : Ragam Latihan Pramuka, (Bandung: Nuansa Muda, 2013), hlm.4 
organisasi, untuk memenuhi kebutuhan masyarakat, alat bagi organisasi atau negara untuk mencapai tujuannya. 24

Pendidikan yang dilaksanakan dalam gerakan pramuka adalah dengan cara menarik dan menyenangkan, bermain sambil belajar seperti menghapal sambil bernyayi, melakukan permainan yang mengandung kebersamaan, saling memahami toleransi dengan perbedaan sudut pandang, kepemimpinan serta bertanggongjawab baik terhadap diri sendiri maupun kelompok (regu) dari fungsi kepramukaan ini maka diharapkan akan membentuk karakter kepemimpinan yang mamapu menciptakan kedamaian melalui toleransi dan tanggung jawab yang dimiliki pramuka dengan berlandaskan kepada Tri Stya dan Dasa Dharma pramuka.

\section{d. Kode Kehormatan Gerakan Pramuka}

Kode kehormatan adalah suatu norma atau nilainilai luhur dalam kehidupan para anggota gerakan pramuka yang merupakan ukuran atau standar tingkah laku seorang anggota gerakan pramuka. Kode keormatan terdiri dari dua macam, yaitu Tri Satya dan Dasa Darma.

Tri Satya: Demi kehormatanku aku berjanji akan bersungguh-sungguh Menjalankan kewajibanku terhadap Tuhan Yang Maha Esa, Negara Kesatuan Republik Indonesia dan mengamalkan Pancasila. Menolong sesama hidup dan ikut serta membangun masyarakat.Serta menepati dasa darma. ${ }^{25}$

Dasa Darma Pramuka: Pramuka itu $\left.{ }^{26}: 1\right)$ Taqwa kepada Tuhan Yang Maha Esa. 2) Cinta alam dan kasih sayang sesama manusia. 3) Patriot

\footnotetext{
${ }^{24}$ Ibid, hlm. 5

${ }^{25}$ Ibid, hlm.52

${ }^{26}$ Ibid,hlm. 59
}

Fikri, Vol. 3, No. 1, Juni 2018 
yang sopan dan kesatria. 4) Patuh dan suka bermusyawarah. 5) Rela menolong dan tabah. 6) Rajin, tampil, dan gembira. 7) Hemat, cermat, dan bersehaja. 8) Disiplin berani dan, setia. 9) Bertanggungjawab dan dapat dipercaya. 10) Suci dalam pikiran, perkataan dan perbuatan.

Jadi dengan adanya kode kehormatan bagi gerakan pramuka, diharapkan pola tingkah laku atau tindakan para anggota Gerakan Pramuka pandega yang ada di Perguruan Tinggi akan menjadi lebih baik sesuai dengan tujuan dan sasaran dari pendidikan Gerakan Pramuka seperti tercantum dalam anggaran dasar Gerakan Pramuka. Muatan-muatan dari Trisatya dan Dasa Darma sudah mencakup seluruh aspek karakter peserta didik, dengan melaksanakan Trisatya dan Dasa Darma dengan sungguh-sungguh maka akan terbentuk pula karakter baik bagi peserta didik itu sendiri.

e. Strategi Pembentukan Karakter Kepemimpinan Anggota Pramuka Institut Agama Islam Negeri (IAIN) Metro. ${ }^{27}$

Ada beberapa strategi yang dapat digunakan dalam membentuk karakter kepemimpinan yang baik melalui kegiatan ekstrakurikuler pramuka IAIN Metroyaitu :1). Intervensi, adanya campur tangan Institusi, Pembina dan pelatih terhadap kegiatan dilakukan anggota ekstrakurikuler pramuka dengan peserta didik, hal ini harus dilakukan secara terus menerus dengan tujuan agar karakter yang ditanamkan kepada peserta didik dapat mendarah daging pada jiwa peserta didik. Pembinaan dapat dilakukan dengan cara memberikan perhatian khusus seperti pengajaran, pengarahan, latihan rutin dan bahkan membuat aturan yang harus dipatuhi oleh peserta 2010-2015

${ }^{27}$ Program Kerja Pembinaan Anggota Pramuka STAIN Metro Periode 
didik.2). Pemberian Keteladanan, Pembina pramuka adalah sebagai artis atau model bagi peserta didik. Jadi seorang Pembina pramuka harus mampu menjadi teladan yang baik untuk peserta didiknya. Karena apa yang dilakukan oleh pembina pramuka akan banyak ditiru oleh peserta didik. Jadi pembina pramuka harus memiliki sikap positif yang baik dan ditampakkan kepada peserta didik agar dapat ditiru atau dicontoh oleh para peserta didik. Sebagai contoh jika seorang pembina pramuka atau dosen ingin menanamkan sikap disiplin pada pembina hal pertama yang harus dilakukan oleh pembina pramuka adalah dengan dimulai dari keteladanan dari pembina dan dosen yang lain. Dengan demikian akan lebih mudah dalam penanaman kedisiplina terhadap peserta didik. Cara ini lebih efektif dari pada pembina pramuka dan dosen harus memberika beribu-ribu nasihat, perintah dan larangan kepada peserta didik.Kepekaan seorang peserta didik dalam melihat dan menganalisis sebuah fenomena yang terjadi di tengah-tengah kesehariannya akan mampu menginsfirasi mindset berpikirnya, oleh karena itu strategi pembentukan karakter kepemimpinan yang baik melalui keteladanan itu sangat baik untuk dilakukan. Sehingga keteladanan itu akan ditiru dan dipraktekan serta tersampaikan kepada orang lain ketika seorang pesrta didik menjadi Pembina atau pemimpin Gugus Depan tempatnya mengabdi.3). Pembiasaan, merupakan sikap seseorang yang dilakukan secara terus menerus. Pembiasaan ini apabila dilakukan secara terus menerus akan menentukan karakterkepemimpinan seseorang. Pembiasaan ini tidak selalu benar, oleh karena itu hanya pembiasaan yang benar saja yang harus tetap dibiasakan. Sedangkan kebiasaan yang buruk akan menimbulkan karakter kepemimpinan yang buruk 
pada peserta didik. Jadi kebiasaan buruk ini harus dihilangkan dari sifat seorang Pembina atau peserta didik. Mungkin akan sulit untuk menghilangkannya, tapi ada pepatah yang mengatakan orang menjadi bisa karena terbiasa.Didalam pramuka pembiasaan itu termasuk dalam nilai-nilai dasadarma.4). Pendampingan, merupakan suatu fasilitas yang diberikan pendamping ekstrrakurikuler terhadap berbagai kegiatan yang diberikan kepada peserta didik. Agar pendidikan karakter kepemimpinan yang ditanamkan kepada peserta didik dapat dilaksanakan dengan baik dengan pengawasan dari seorang Pembina pramuka maupun dosen.5). Penguatan, penanaman karakter kepemimpinan yang diberikan kepada peserta didik lewat kegiatan ekstrakurikuler pramuka harus mendapatkan penguatan dari seorang Pembina pramuka. Tujuannya untuk memperkuat karakter positif peserta didik.6). Keterlibatan BerbagaiPihak, dalam pelaksanaan ekstrakurikuler pramuka di Institut Agama Islam Negeri (IAIN) Metro harus ada keterlinbatan dari berbagai pihak. Seperti, Rektor( Ka.Mabigus), Warek I Sebagai Anggota Majelis Pembimbing Gugus Depan Warek II Sebagai bendahara Majlis Gugus Depan Warek III sebagai Ketua Harian Gerakan Pramuka,

Strategi tersebut di atas apa bila dilaksanakan dengan baik maka akan melahirkan peserta didik yang berkarakter, mudah dikendalikan dan mau menerima masukan dan memberi masukan, siap dipimpin dan memimpin dirinya dan orang lain.

\section{f. Pembentukan Karakter Kepemimpinan Melalui Kegiatan Perkemahan ${ }^{28}$}

\section{${ }^{28}$ Ibid}


Terbentuknya pribadi dan karakter mandiri melalui kegiatan perkemahan merupakan salah satu perwujudan yang dapat dilihat dan diamati bahwa Pramuka di Perguruan Tinggi, pembentukan jiwa yang tangguh, tidak cepat putus asa, kedisiplinan, dan kematangan emosional juga menjadi tujuan dan sasaran kegiatan perkemahan. Di dalam perkemahan, semua kegiatan baik kegiatan pribadi maupun kegiatan kelompok/regu harus dikelola dan dilakukan oleh pribadi dan regu masingmasing yang di pimpin oleh seorang ketua regu. Ini merupakan bentuk nyata dari penciptaan kemandirian, dan sebuah tanggung jawab yang diajarkan dalam kegiatan pramuka, sehingga anggota pramuka memiliki karakter tanggungjawab, peka, disiplin, berani, dan jujur.

Kecerdasan sosial pun terbentuk dalam kegiatan perkemahan.Dalam Gerakan Pramuka dikenal dengan satuan regu yang terdiri dari sekurang-kurangnya 8 orang anggota. Ketika program perkemahan diselenggarakan, kelompok dalam satu regu akan berinteraksi untuk mengengelola dan mempersiapkan perkemahan. Sikap saling menghormati dan toleransi antar sesama pramuka, sikap saling menghargai, dan sikap peduli atau empati akan teruji dalam kelompok ini. Dengan demikian maka akan terlahirlah rasa saling menghargai, kesabaran, jiwa sosial dan kematangan emosional peserta didik , oleh karena itu rasanya tidak berlebihan bila mana Pramuka dimasukan menjadi kegiatan ekstrakurikuler wajib dalam kurikulum 2013 di SD/MI, SMP, MTs, SMA, MA dan sederajat serta Perguran Tinggi sebagai pencetak calon-salon guru. 


\section{g. Pembentukan Karakter Kepemimpinan Melalui Bakti Sosial $^{29}$}

Kurangnya antusias dan perhatian pemuda terhadap warga yang tinggal ditempat terpencil, sehingga Pramuka berinisiatif membangun rasa kepedulian tersebut melalui kegiatan bakti sosial.Kegiatan ini juga merupakan kelanjutan dari membangun keakraban antar sesama. Salah satu contoh bahwa Gerakan Pramuka IAIN Metro memiliki Desa Binaan di 23 Karang Rejo sebagai tempat pengabdian dan menumbuhkan jiwa sosial dan toleransi antar agama serta budaya, dari kebiatan ini diharpkan mampu melahirkan anggota pramuka yang berjiwa sosial dan menjunjung rasa toleransi antar budaya, sehingga kelak akan melahirkan karakter pemimpin yang baik,mampu mengayomi semua lini dan keberadaanya membawa kebahagiyaan masyarakat bukan malah menjadi kegelisahan masyarakat.

\section{h. Pembentukan Karakter Kepemimpinan Melalui Keagamaan $^{30}$}

Adapun kegiatan keagamaan di dalam pramuka adalah berlandaskan kepada dasa darhma ke 1) Taqwa kepada Tuhan Yang Maha Esa 9) Bertanggungjawab dan dapat dipercaya. 10) Suci dalam pikiran, perkataan dan perbuatan. Melalui pengajian perkemahan seperti, shalat berjamaah, shalat tahajud, shalat, serta kegaiatan rutin seminggu sekali setiap hari jumat sore, pengajian risma di desa binaan, serta pengajian ibu-ibu. Dengan kegaiat yang dirancang dalam kebersamaan ini diharapkan mampu mencetak calaon generasi yang berkarakter baik dan berjiwa toleransi.

\section{i. Pemembentukan karakter kepemimpinan melalui TRI BINA PRAMUKA ${ }^{31}$}

\section{${ }^{29}$ Ibid \\ ${ }^{30}$ Ibid}


Bina diri;Anggota pramuka Institut Agama Islam Negeri (IAIN) Metro harus melakukan Bina diri yaitu membekali dirinya dengan ilmu pengetahuan agama maupun umum serta kemampuan skill individu yang baik sehingga akanmampu melakukan yang terbaik dilingkungan tempatnya bekerja. Bina satuan; Anggota pramuka IAIN Metro di kader agar mampu melakukan kegiatan kerjasama dalam sebuah kelompok yang baik sehingga terciptanya rasa tanggongjawab terhadap diri sendiri dan anggota yang lain, hal ini tidak mudah dilakukan butuh waktu yang lama untuk menciptakan rasa tanggungjawab, memahami karakter anggota kelompok yang berbeda-beda, toleransi terhadap perbedan pendapat. Sampai terbangunnya rasa kenyamanan dan tumbuhnya toleransi yang baik. Bina satuan inilah yang biasa dilakukan dengan cara permainan Outbon mencari kader calaon pemimpin yang berkarakter baik.Bina masyarakat;Sementara bina masyarakat diajarkan kepada anggota pramuka agar tumbuh kepedulian terhadap sesama dengan bentuk gotong royong, bakti sosial, serta keagamaan. Kepekaan,kreatif, inovatif, anggoat pramuka dalam hal ini sangat diperlukan, agar tumbuh kematangan kederdasan sosial dan kecerdasan emosional anggoat pramuka Institut agama Islam Negeri (IAIN) Metro.

\section{j. Pemembentukan karakter kepemimpinan melalui Praktek Baris Berbaris}

Kegiatan praktek baris berbaris (PBB) ini di harapkan akan tertanam sebuah kedisiplinan dan rasa tanggungjawab pada diri sendiri dan orang lain semua anggota harus patuh kepada aba-aba pemimpin, harus mengedepankan rasa kebersamaan dan toleransi.

\section{${ }^{31}$ Ibid}

Fikri, Vol. 3, No. 1, Juni 2018 


\section{k. Pemembentukan karakter kepemimpinan melalui praktek tali temali.}

Kegaiatan ini diharapkan peserta didik akan mampu memiliki ide-ide kriatif, mampu berbuat yang terbaik baik bagi diri sendiri maupun orang lain seperti dengan kemampuan membauat tali temali peserta didik mamapu membuat tandu kapanpun diperlukan, sebagai solusi turun dari tempat yang tinggi ketika tidak ada jalan dan tangga melalui simpul hidup dan simpul korsi maka peserta didik dapat menyelamatkan orang banyak. Dengan demikian maka akan tertanam kecerdasan sosial, emosional, dan toleransi.

Dari berbagai kegiatan pramuka Institut Agama Islam Negeri (IAIN) Metro di atas maka diharapkan akan mamapu mencetak calaon-calon pemimpin yang memiliki kepekaan terhadap setuasi dan kondisi yang ada, bertanggungjawab, disiplin, jujur, membangun toleransi di tengah -tengah kemajemukan mahasiswa dan masyarakat yang ada, sehingga mampu membawa perobahan karakter kepemimpinan mahasiswa yang lebih baik memunculkan gagasan-gagasan yang cemerlang mengedepankan kepentingan Intitusi IAIN Metro di atas kepentingan dirisendiri dan golongan.

\section{Pembahasan}

\section{Peran UKK Pramuka dalam Membentuk Karakter Kepemimpinan}

Pembinaan karakter mahasiswa harus bersifat praktikal. Dalam hal ini, pramuka sebagai kegiatan ekstrakurikuler menjadi salah satu solusinya, disamping pembinaan langsung yang diajarkan dosen dalam kegiatan perkuliahan. Peran Pramuka mengajarkan sikap-sikap yang dibutuhkan mahasiswa saat ini seperti keberanian, kepemimpinan, kejujuran, kesederhanaan, keyakinan, cinta alam, cinta tanah air dan sebagainya. 
Berdasarkan penyajian data diatas melalui hasil wawancara dan observasi dapat diketahui bahwa peran UKKPramuka Racana Radin Intan II dan Putri Kandang Rarangsangatlah membantu dalam pembentukan karakter kepemimpinan, terlebih di dalam nya terdapat kegiatankegiatan yang positif yang mampu membentuk sikap kemandirian, tanggung jawab, kedisiplinan dan kematangan emosional. Adapun upaya yang sudah dilakukan yaitu melalui kegiatan-kegiatan yang mampu mengajarkan sesuatu yang baik, contohnya mengajarkan bagaimana berbicara yang sopan, berpakaian rapi, mengajarkan harus tepat waktu dan menanamkan rasa tanggung jawa yang tinggi terhadap adik-adik dan anggota pramuka. Selain itu agar anggota pramuka memiliki karakter kepemimpinan, UKK Pramuka membuat aturan yang harus dipatuhi semua anggota racana.

SelanjutnyaUKK Pramuka tentu berperan penting dalam membentuk karakter kepemimpinan karena melatih fisik dan mental dalam potensi diri masingmasing individu. Untuk membentuk suatu pemikiran yang tertanam dalam dirinya masing-masing karena di pramuka terdapat semua kegiatan yang bisa membuka karakter kita.Tujuan dari pramuka tersebut sendiri adalah untuk mendidik dan membina semua remaja untuk mendidik mental intelektual, karakter, moral para remaja untuk menjadi pemuda yang baik dan mengembangkan bakat yang mereka punya.

\section{Faktor Pendukung dalam membentuk Karakter Kepemimpinan Anggota Pramuka IAIN Metro}

Faktor pendukung merupakan hal yang terpenting dalam rangka membentuk karakter anggota pramuka IAIN Metro.Adapun Peran UKK Pramukadalam proses tersebut 
telah mengalami banyak kendala dari tahun ke tahun. Kendala yang ada merupakan masalah klasik, tetapi hal itu tidak menjadi beban bagi UKK Pramuka dalam mengembangkan semua program-programnya terutama program wajib yaitu pembinaan skill anggota. Ada beberapa faktor pendukung yang sangat menunjang pembentukan karakter kepemimpinan anggota pramuka IAIN Metro diantaranya: Faktor pendukung mengenai pembentukan karakter kepemimpinan yang ada di gugus depan IAIN Metro sangat produktif hal ini terlihat sebagaian besar Dewan Racana telah memiliki sertifikat KMD bahkan KML hal ini sangat menunjang dalam melahirkan kader-kader pemimpin yang baik, selain itu adanya kerja sama yang baik antara gugus depan IAIN Metro dengan Kwartir Ranting, Kwarcab Kota Metro bahkan Kwarda lampung, menjadi senjata untuk mendatangkan pemateri dan pelatih yang handal, banyaknya alumni yang menjadi dosen dan staf di Intitusi IAIN Metro dapat dijadikan motifasi bagi kaderkader pramuka untuk terus berbuat dan mengabdi serta melakukan yang terbaik, contohnya seperti bina diri, bina satuan serta bina masyarakat, kemudian banyaknya jalinan mitra kerja dengan gugus depan di Kota Metro sangat menunjang keberhasilan Praktek Pengalaman Lapangan (PPL) Pramuka Racana Radin Intan II dan putri Kandang Rarang gugus depan IAIN Metro.

Selanjutnya dengan adanya dukungan dari pengurus majelis pembimbing gugus depan IAIN Metro menambah energi kekuatan dewan racana untuk selalu mengembangkan kegiatan pramuka. Selain itu faktor-faktor yang mendukung dalam membentuk karakter kepemimpinan anggota pramuka yaitu adanya dukungan dari berbagai pihak, seperti majelis pembimbing gugus depan serta dukungan motivasi yang tinggi dari alumni atau purna UKK Pramuka IAIN Metro, selanjutnya keaktifan anggota racana juga menjadi salah satu faktor pendukung dalam membentuk karakter kepemimpinan.

\section{Faktor Penghambat dalam Membentuk Karakter Kepemimpinan Anggota Pramuka IAIN Metro}


Dalam rangka membentuk karakter kepemimpinan anggota racanabahwa ada banyak faktor yang menjadi kendala baik secara langsung maupun tidak langsung yang mempengaruhi proses dalam pembentukan karakter kepemimpinan. Keberhasilan dalam proses latihan maupun kegiatan tidak terlepas dari keaktifan dan kemampuan seorang pelatih dalam melakukan pendampingan kegiatan. Selain itu, adanya anggota pramuka yang hanya masuk pramuka hanya sekedar ikut kawan dan ingin coba-coba menjadi kendala untuk aktif dalam kegaiatan pramuka.

Selanjutnya yang menjadi faktor penghambatnya yakni adanya anggota yang kurang memahami dalam memaknai organisasi sehingga tingkat antusias anggota untuk turut aktif dalam kegiatan rendah. Padahal, organisasi pramuka merupakan wadah untuk belajar baik secara teori dan praktik serta membentuk karakter dan skill secara individu maupun kelompok. Tidak hanya kurangnya pemahaman anggota terhadap organisasi saja, tetapi fasilitas juga menjadi faktor penghambat. Karena organisasi apapun, kegiatan dalam bentuk apapun jika fasilitas/sarana prasarana organisasi tidak menunjang maka akan menjadi penghambat dalam menjalankan program kerja. Terlebih sarana yang dibutuhkan UKK Pramuka adalah alat out door game.Permainan yang bersifat lapangan sangat berpengaruh terhadap pembentukan karakter seseorang. Mengingat di dalamnya terdapat kebersamaan yang menyenangkan, kekompakan, keberanian, tolong menolong dan lain sebagainya.Adapun yang menjadi kendala selain tingkat keaktifan anggota yang rendah, fasilitas yang kurang memadai, ternyata yang menjadi dominan adalah 
minimnya anggaran dana untuk menunjang kegiatankegiatan pramuka.

4. Solusi Dewan Racanayang dilakukan untuk MengatasiHambatan dalam membentuk Karakter Kepemimpinan Anggota Pramuka IAIN Metro

Solusi yang diberikan olehDewan Racana dalam mengatasi hambatan-hambatan yang dihadapi UKK Pramuka dalam pembentukan karakter kepemimpinan anggota pramuka Racana Radin Intan II dan Putri Kandang Rarang Gugus Depan IAIN Metro. Hal yang lain yaitu tentang minimnya dana, memang sudah menjadi makanan pokok bagi setiap organisasi. Namun, setiap organisasi jangan sampai menjadikan hal tersebut sebagai alasan klasik. Organisasi harus mampu dan bahkan dituntut harus berani mengambil langkah demi menepis kebiasaan berfikir bahwa minimnya anggaran sebagai penghambat kegiatan. Dalam hal ini, UKK Pramuka IAIN Metro dapat dikategorikan sudah berani mengambil keputusan yakni menjalin kerja sama dengan BMT dan usaha kecil PKBM Al Suroya. Dengan demikian UKK Pramuka IAIN Metro bisa mendapat sedikit pemasukan dana untuk menunjang ataupun menopang kegiatan-kegiatan pramuka.

Kerja sama dalam organisasi memang sangat diperlukan, karena yang menjalankan organisasi adalah manusia. Sedangkan manusia adalah makhluk sosial yang tidak bisa terlepas dari bantuan orang lain. Jalinan-jalinan kerja sama UKK Pramuka IAIN Metro sudah di lakukan dengan cukup baik, karena pihak-pihak yang dituju untuk menjalin kerja sama adalah organisasi, instansi-instansi, sekolah dan desa yang tidak diragukan lagi gaungnya.

Kwarcab merupakan salah satu organisasi pramuka yang secara silsilah organisasi adalah pengurus gerakan pramuka cabang atau kepengurusannya ada di tingkat kota yang bisa menjadi acuan dan panutan bagi organisasi pramuka lainnya. Terlebih lagi lembaga sekolah dari tingkat SD sampai SMA yang dijadikan tempat untuk pelaksanaan PPL menjadi sebuah 
tolak ukur sejauh mana kemampuan yang telah dimiliki anggota pramuka IAIN Metro dalam menguasai teori dan praktik tentang ilmu kepramukaan.

Kerja sama yang terakhir adalah dengan Desa Karang Rejo Kecamatan Metro Utara. Ini merupakan hal sebuah puncak dari fungsi UKK pramuka karena jika dilihat dari sejarah berdirinya gerakan pramuka di Indonesia adalah berawal dari masyarakat desa dimana masayarakat desa sangat identik dengan salah satu konsep pendidikan yang ada di Indonesia yaitu konsep pendidikan Non formal. Pendidikan non formal memberikan kebebasan kepada masayarakat untuk mengenyam pendidikan dengan tidak tersistem layaknya pendidikan formal. Maksudnya adalah kegiatan, aktifitas dan rutinitas masyarakat baik sosial maupun sosial ataupun komersial pada hakikatnya adalah kegiatan pendidikan yang dilakukan secara tidak sadar. Maka dari itu masyarakat sangat cocok untuk dijadikan media langsung dalam pendidikan dan pelaksanaan program UKK Pramuka yang berkaitan dengan Tri Bina Pramuka.

\section{Kesimpulan}

1. Peran UKK Pramuka dalam membentuk karakter kepemimpinan,terdapat kegiatan-kegiatan yang positif yang mampu membentuk sikap kemandirian, tanggung jawab, kedisiplinan dan kematangan emosional. Adapun upaya, UKK Pramuka membuat aturan yang harus dipatuhi semua anggota racana.

2 Faktor pendukung dalam membentuk karakter kepemimpinan Anggota Pramuka IAIN Metro adalahadanya dukungan dari berbagai pihak, seperti majelis pembimbing gugus depan serta dukungan motivasi yang tinggi dari alumni atau purna UKK Pramuka IAIN Metro, Selanjutnya mengenai pembentukan karakter kepemimpinan yang sangat produktif hal ini terlihat sebagaian besar Dewan Racana telah memiliki sertifikat KMD bahkan KML hal ini sangat menunjang dalam melahirkan kader-kader pemimpin yang baik, adanya kerja sama yang 
baik antara gugus depan IAIN Metro dengan Kwartir Ranting, Kwarcab Kota Metro bahkan Kwarda lampung

3. Faktor penghambat dalam membentuk karakter kepemimpinan anggota pramuka IAIN Metro adalah adanya anggota yang kurang memahami dalam memaknai organisasi sehingga tingkat antusias anggota untuk turut aktif dalam kegiatan rendah. fasilitas yang kurang memadai, ternyata yang menjadi dominan adalah minimnya anggaran dana untuk menunjang kegiatan-kegiatan pramuka.

4. Solusi Dewan Racana yang dilakukan untuk Mengatasi Hambatan dalam membentuk Karakter Kepemimpinan Anggota Pramuka IAIN Metro yaitu menjalin kerja sama dengan BMT dan usaha kecil PKBM Al Suroya. Selain itu UKK pramuka juga menjalin kerjasama dengan Instasi-instasi seperti lembaga sekolah dari tingkat SD sampai SMA yang dijadikan tempat untuk pelaksanaan PPL, Kerja sama yang terakhir adalah dengan Desa Karang Rejo Kecamatan Metro Utara.

\section{Daftar Pustaka}

Andri Bob Sunardi, Boyman :Ragam Latihan Pramuka, Bandung: Nuansa Muda, 2013

Andri Bob Sunardi, Boyman :Ragam Latihan Pramuka, Bandung: Nuansa Muda, 2013

Anton Suwito, IntegrasiNilaiPendidikanKarakterKedalam Mata

PelajaranPendidikanKewarganegaraan di

SekolahMelalui RPP, (JurnalIlmiah CIVIS Vol. 2 No. 2, 2012)

Ahmad, Syarwani, Muhammad Kristiawan, Tobari Tobari, dan Suhono Suhono. "Desain Pembelajaran SMA Plus Negeri 2 Banyuasin III Berbasis Karakter Di Era Masyarakat Ekonomi ASEAN." Iqra': Jurnal Kajian Ilmu Pendidikan 2, no. 2 (2017): 403-402. 
Cholid Narbuko, Abu Achmadi. Metodologi Penelitian. Jakarta: Bumi Aksara, 2012

Djam'an Satori, AanKomariah,Metodologi Penelitian Kualitatif, Cet. 4, Bandung: Alfabeta, 2012

Doni Koesoema A, Pendidikan Karakter Strategi Mendidik Anak di Zaman Global .Jakarta: Grasindo, 2010.

DwiYuni Lestari,Pembinaan Karakter Siswa di SMP Nasional Pati, Jurnal Ilmiah PPKN IKIP Veteran Semarang, tt

Fitriono, Eko Nani, dan Suhono Suhono. "Wacana Negara Islam: Kajian Kritis Kontruksi Pemikiran Khilafah Ala Hizbut Tahrir." Ri'ayah: Journal of Social and Religious 2, no. 02 (2017): 43-55.

Heri Cahyono, Suhono Suhono, dan Aisah Khumairo. "Peendidikan Karakter Bagi Pelaku Pedofilia (Sebuah Strategi Dalam Mengatasi Amoral)." JMKSP (Jurnal Manajemen, Kepemimpinan, dan Supervisi Pendidikan) 3, no. 1 (2018): 8.

Suhono, Suhono, dan Ferdian Utama. "KETelADANAN ORANG TUA DAN GURU DALAM PERTUMBUHAN DAN PERKEMBANGAN ANAK USIA DINI." Elementary: Jurnal Ilmiah Pendidikan Dasar 3, no. 2 (2017): 107-119.

Kartini Kartono, Pemimpin dan Kepemimpinan, Jakarta: PT. RajaGrafindo Persada, 1983

M. Ngalim Purwanto, Administrasi dan Supervisi Pendidikan, Bandung: Remaja Rosdakarya, 1991

Miftah Thoha, Kepemimpinan dalam Manajemen, Jakarta: Rajawali Pers, 1983

MuchlasSamani, Hariyanto, Konsepdan Model PendidikanKarakter,Bandung: Remaja Rosdakarya, 2012.

Program Kerja Pembinaan Anggota Pramuka STAIN Metro Periode 2010-2015

Ridwan, N. A. Landasan Keilmuan Kearifan Lokal. Ibda P3M STAIN Purwokerto, 2007. Vol 5 No.1 , 27-38.

S. Nasution. Metode Research. Jakarta: Bumi Aksara, 2011 
Sartini.Menggali Kearifan Lokal Nusantara Sebuah Kajian Filsafati . Jurnal Filsafat, 2004. Jilid 37, Nomor 2 ,h. 111.

Stephen P. Robbins, Prinsip-prinsip Perilaku Organisasi, Jakarta: Erlangga, 2002

Suharsimi Arikunto,Prosedur Penelitian Suatu Pendekatan Praktek,Cet. 12, Jakarta: Rineka Cipta, 2002

Suharsimi Arikunto.Prosedur Penelitian, Suatu Pendekatan Praktik. Jakarta: Rineka Cipta, 2010

Suparlan, Parsudi. 2002, Menuju Masyarakat Indonesia Yang Multikultural, Makalah, Disajikan pada Simposium Internasional Jurnal Antropologi Indonesia ke-3, Universitas Udayana, Denpasar, Bali, 16-19 Juli 2002.

Tim Penyusun Tesaurus, Tesaurus Alfabetis Bahasa Indonesia Pusat Bahasa .Bandung: Mizan Pustaka, 2009

Undang-Undang Nomor 12 tahun 2010 tentang Gerakan Pramuka Pasal 1 ayat 1-3.

Undang-undang Nomor 12 tahun 2010 tentang Gerakan Pramuka Pasal 7 ayat 5

Undang-Undang Republik Indonesia No 12 Tahun 2010 Tentang Gerakan Pramuka. 